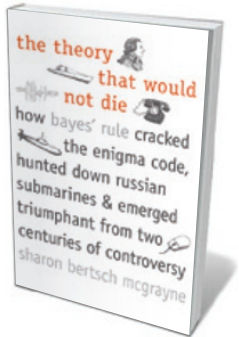

The Theory That Would Not Die:

How Bayes'

Rule Cracked

the Enigma

Code, Hunted

Down Russian

Submarines

and Emerged

Triumphant from

Two Centuries of

Controversy

SHARON BERTSCH

MCGRAYNE

Yale University Press:

2011. 336 pp. $\$ 27.50$

storage. Publication of the method used to decode Enigma was embargoed under the Secrets Act until the 1990s. During the 1950 s, the influential statistician and geneticist R. A. Fisher continued his long-standing battle against Bayes' theorem, calling it an "impenetrable jungle". When Good discussed the theorem at Britain's Royal Statistical Society, the next speaker began: "After that nonsense...".

In the United States, the small group of Bayesian statisticians came under suspicion as outsiders. During the McCarthy period of anti-communist sentiment, they were even considered 'un-American'. Professors at Harvard Business School referred to their Bayesian colleagues as "socialists and so-called scientists".

Meanwhile, the US military and government were both applying Bayes' theorem, if reluctantly. In a gripping chapter, McGrayne describes how it was used in trying to find a hydrogen bomb that fell from a B-52 jet into the sea off Spain in 1966, and a US nuclearpowered attack submarine that disappeared in the Atlantic Ocean in 1968. President Lyndon B. Johnson raged to the investigating team: "I don't want this probability stuff. I want a plan that tells me exactly when we're going to find this bomb."

In the event, Bayes' theorem was not needed. The missing bomb was located in an ocean canyon following a tip from a fisherman who had seen a parachute splash down near his boat. As for the Bayesian search for the submarine in the Atlantic, the consensus is that it would have succeeded had faster computers been available in 1968. Highspeed computing is the main reason that Bayesian methods shook off their detractors and acquired their present-day prominence, McGrayne emphasizes.

For all the book's skilful mingling of ideas and intriguing personal details, I found it sloppy on occasions. Tautologies slip in, and evidence is lacking for some claims. Nonetheless, The Theory That Would Not Die is a rollicking tale of the triumph of a powerful mathematical tool. -

Andrew Robinson is author of The Man Who Deciphered Linear B: The Story of Michael Ventris.

e-mail: andrew.robinson33@virgin.net

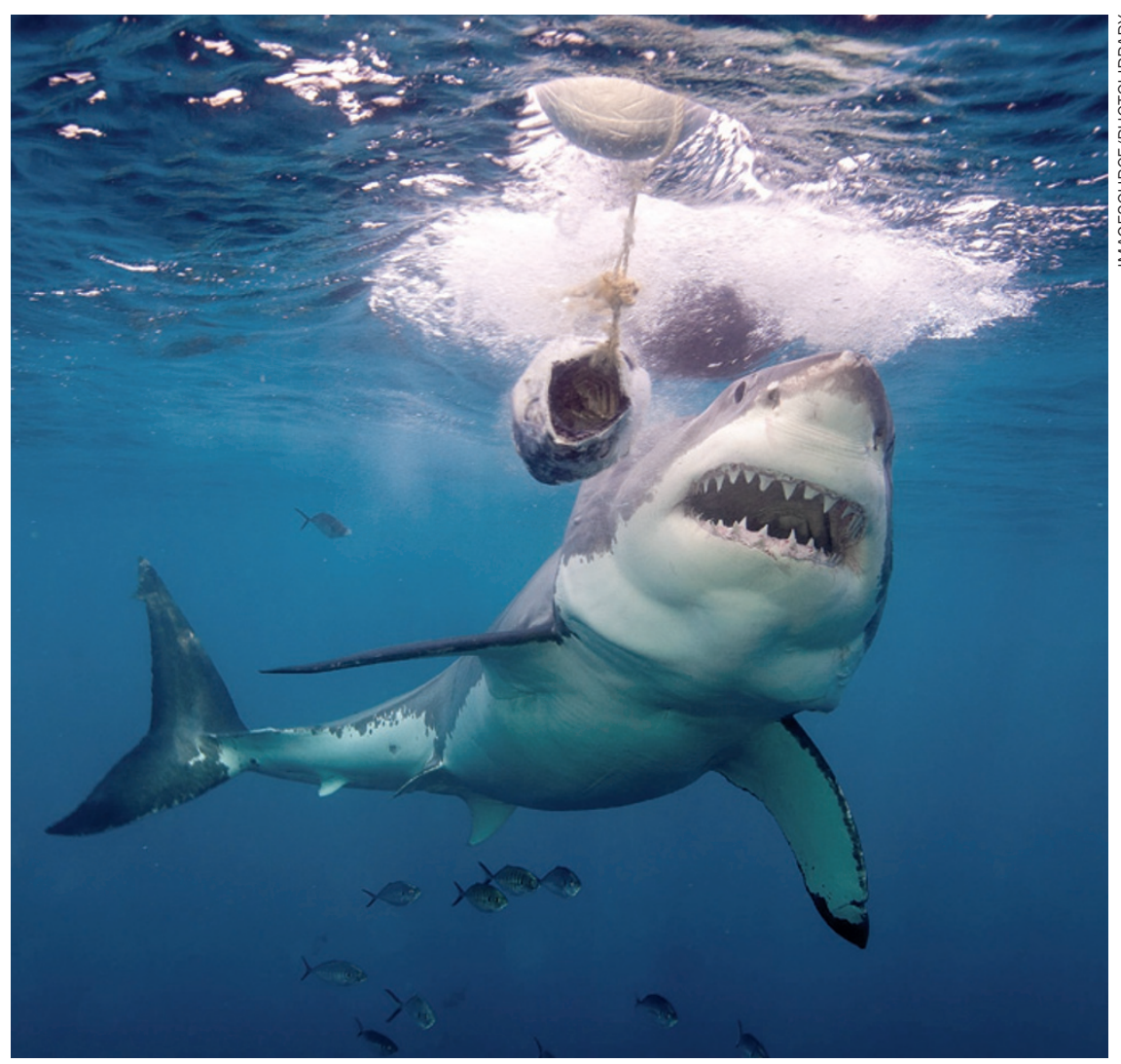

Sharks are more threatened by humans than we are by them, yet the great white still gets a bad press.

MARINE SCIENCE

\title{
Saving the shark
}

\section{Steven Campana enjoys a refreshing account of human pressure on the oceans' top predator.}

$\mathrm{H}$ ow do shark-attack deaths differ from those caused by chairs, toasters and falling coconuts? As science journalist Juliet Eilperin explains in Demon Fish, you are about 200 times less likely to be killed by a shark than by a defective toaster.

Her book delves into the uneasy cohabitation of two of Earth's top predators: sharks and humans. People used to coexist with sharks more amiably before the advent of technology, even deeming them gods. But with films such as Jaws as a guide, many now presume that sharks are winning the predatorial race. They are wrong. Sharks are losing, big time.

Eilperin has a refreshingly different take on how humans are contributing to the decline of shark populations around the world. Avoiding sensationalism or dry facts, she inserts herself into the daily lives of the 'shark people' who work with or on the fish. Eilperin begins her journey by digging into the psyche of the 'shark callers' of Papua New Guinea, who use rattles to lure the creatures from the deep before catching them with handheld snares, thereby demonstrating their divine connections with the shark. She then interviews shadowy buyers of shark fins in Asia; larger-than-life shark

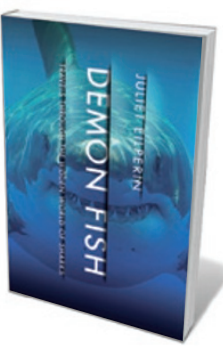

Demon Fish: Travels Through the Hidden World of Sharks

Pantheon: 2011

320 pp. $\$ 26.95$
JULIET EILPERIN charter operators; the family of Peter Benchley, author of the 1974 novel Jaws; dedicated conservationists; and quirky shark biologists. All are portrayed in entertaining detail.

Her book draws the reader into the world of these frequently bombastic characters. One charter-boat owner who operates out of Florida boasts 
of having killed 100,000 sharks, and specializes in hunting the biggest he can find. As he tries to satisfy the fishing needs of his clientele, you begin to see through his business-oriented eyes. Yet any appreciation soon disappears when Eilperin notes his propensity for targeting a thresher shark birthing ground, or his desire to catch and kill pregnant hammerheads because they are larger.

In one of the most insightful chapters - the best I've read on the subject - Eilperin describes how the burgeoning demand for shark-fin soup in Asian markets is a leading cause of the shark's global population decline. Many sharks are now caught and killed solely for the value of their fins - up to US $\$ 2,000$ per kilogram. The edible yet less-valuable carcass of the still-living shark is sometimes simply thrown back into the water. Eilperin meets elusive fin buyers and sellers, who state that if the sharks disappear from the sea altogether, "there's nothing we can do about it".

With up to $\$ 57,000$ being paid for a single basking shark fin, this is big business. Sampling the fabled Chinese wedding soup, the author pulls a tasteless fin strand out of her bowl and concludes that the expensive delicacy is a scam. The chefs she interviews agree, admitting that the fin has no culinary value. A dish that is about style, not substance, may be leading to the demise of entire species.

Although Demon Fish is more about people's attitudes to sharks than fish biology, Eilperin cleverly introduces science into her account. She describes the advocacy positions taken by some marine biologists attempting to stop recreational shark fishing, and relates sometimes-comical first-hand observations of biologists trying to tag sharks. Curious by its absence, however, is any wider discussion of the huge impact of accidental commercial by-catch on shark populations. The author makes the point that the most effective conservation efforts are now being made by market forces such as ecotourism, rather than through abstract environmental idealism.

From the ethics surrounding shark fishing to the delightfully creative methods of shark-conservation groups, including auctioning off naming rights for new species, Demon Fish captures most of the key issues affecting sharks today.

Steven Campana is a research scientist and head of the Canadian Shark Research Laboratory at the Bedford Institute of Oceanography, Dartmouth, Nova Scotia, Canada.

e-mail: steven.campana@dfo-mpo.gc.ca

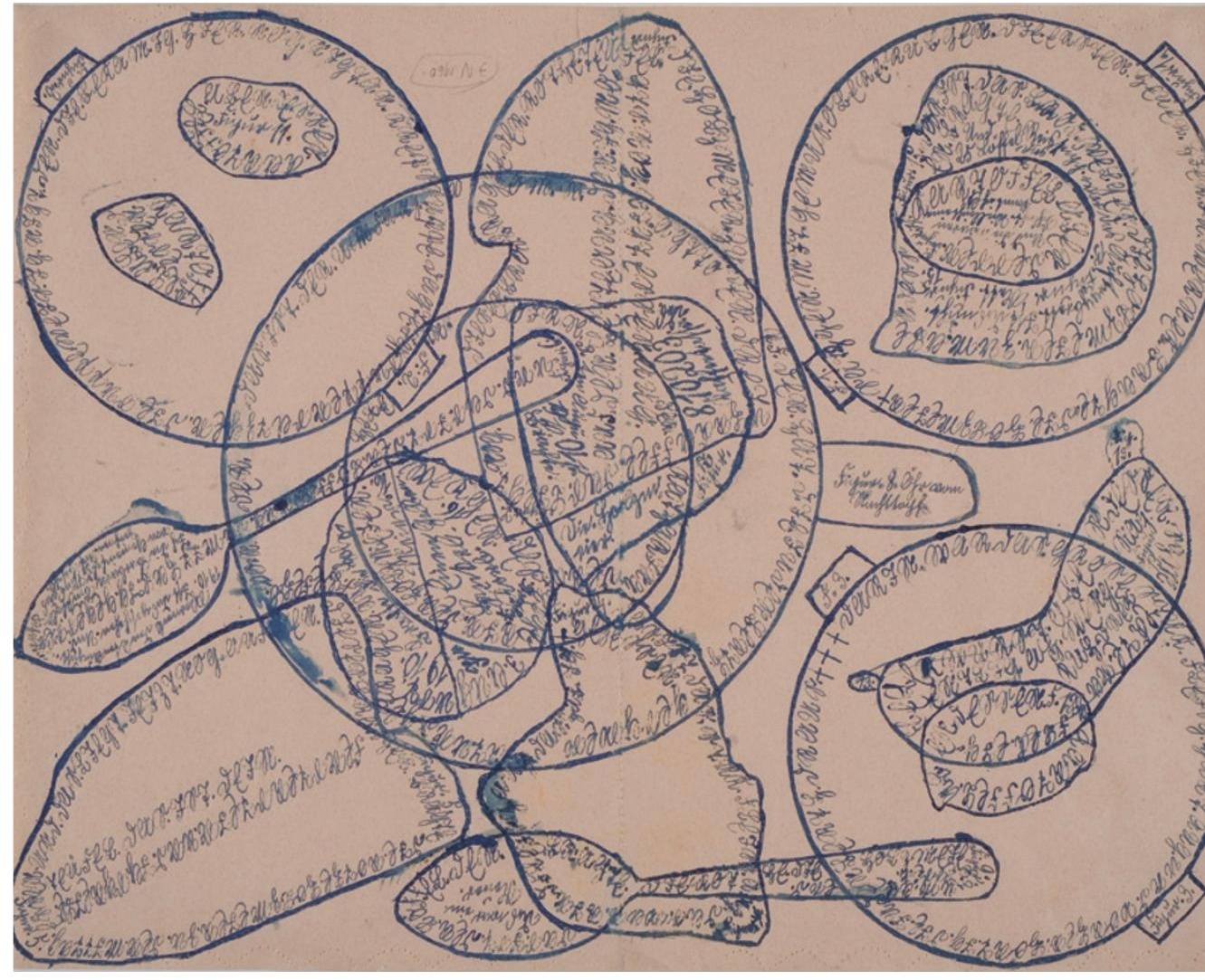

Barbara Suckfüll's 1910 ink drawing incorporates words describing her life as a psychiatric patient.

PSYCHOLOGY

Asylum art

\section{The Prinzhorn museum shows how psychiatric patients' works have inspired artists, finds Giovanni Frazzetto.}

$\mathrm{D}$ uring 1919-21, in a psychiatric clinic in Heidelberg, Germany, the young psychiatrist and art historian Hans Prinzhorn collected more than 5,000 works of art created by about 400 patients. Forgotten for more than 50 years after being condemned as 'degenerate art' during the Nazi regime, the collection was catalogued in the 1980s and housed in a museum in the clinic in 2001.

This year the Prinzhorn Collection Museum celebrates its tenth anniversary, and the 125th anniversary of Prinzhorn's birth, with an exhibition. A selection of original pieces from the collection are paired with works by modern artists who have drawn inspiration from them - including Paul Klee, Ernst L. Kirchner and Max Ernst.

The responses comment on the creativity of the patients, the psychiatric establishment itself and past understandings of mental pathology. Some of the reactions do not quite compete with the authenticity of the original works; others are compelling and eloquent.
Von Kirchner bis heute

(From Kirchner To Today)

Prinzhorn Collection Museum and elsewhere, Heidelberg, Germany. Until 14 August. under their command, she began to draw outlines of dishes and cutlery. Writing along and in between the outlines, Suckfüll captures in words her everyday life in the Heidelberg asylum: what she thought, did or ate, her rows with the nurses and what the voices told her. Every word is followed by a full stop, resulting in a dense net of marks that dissolves into abstraction.

Also on show is a thoughtful series of drawings by Dorothee Rocke, one of the first artists to explore the collection when the museum opened in 2001. She dedicates her work to a 1912 sketch by inmate Hyacinth Freiherr von Wieser, in which 